\title{
Reverse Logistics Management and Enviromental Sustainability Drive in Nigeria (Study of the Food and Drink Industries)
}

\author{
A. E. Ndu Oko ${ }^{1} \&$ Nkamnebe, Anayo D. ${ }^{2}$ \\ ${ }^{1}$ Department of Marketing Abia State University, Uturu, Nigeria \\ ${ }^{2}$ Department of Marketing Nnamdi Azikiwe University, Akwa, Nigeria \\ Correspondence: A. E. Ndu Oko, Department of Marketing Abia State University, Uturu, Nigeria. E-mail: \\ a.e_nduoko@yahoo.com
}

Received: May 7, 2013

Accepted: June 14, 2013

Online Published: July 16, 2013

doi:10.5539/ijbm.v8n16p54

URL: http://dx.doi.org/10.5539/ijbm.v8n16p54

\begin{abstract}
The Nigerian physical environment is generally subjected to various forms of abuse and debasement resulting to water and air pollution and soil degradation as evidenced by large number of heaps of domestic and industrial wastes in major and minor towns of the country. These heaps of refuge (waste) are attributed to inadequate and inefficient reverse logistics management programmes of firms. Hence this work is on reverse logistics management and environmental sustainability drive in Nigeria. The study generated data on the operations of firms in the food and drink industries and the marketing intermediaries and customers of the firms. These data were evaluated and analyzed based on hypotheses using analysis of Variance and Pearson correlation coefficient statistical tools. Findings based on the research work among others is that the firms operating in the food and drinks industries in Nigeria are technologically biased in area of product quality for enhanced corporate efficiency and shareholders' welfare at the expense of reverse logistics programmes to the detriment of the health standard of the general and specific target markets. The research thus recommends improved policies of social responsibility for the firms as well as enhanced regulatory and supervisory functions of the reverse logistic management programme of the firms by government regulatory bodies. Results of this work if adopted will improve the health and environment standard of Nigeria and generate good public image for firms operating in the country.
\end{abstract}

Keywords: littering, easy-to-carry containers, environmental consciousness, lack of dedicated leadership, sustainable marketing orientation, waste producers, re-cycling and re-use

\section{Introduction}

The flow of goods in a supply chain does not end with the consumers or industrial users-Berkowitz, Kerin, Hartley and Rudelius [2000], Atasu, Guide and Van Wassenhore [2008] hence, the greater recognition currently being accorded the reverse logistics in the supply chain-Marien [1998:43-53], Olugu, Wong Kuma, and Shadaroum [2010]. Reverse logistics is differently adopted by organizations, either as integrated logistic or separation logistics based on the services of 3rd party logistics providers- Atasu, Guide and Van Wassenhore [2008] Chou, [2009] Liang and Huang and Agrawal, Atasu, and Van Ittersum, [2012], Jacobs and Subranabian [2012] and Andel and Aichlmayr [2002].

In some developed economies, organizations are not only interested in the management of their shipments of new products between plants, distribution centers, and retailers but also the movement of used products destined for recycling Souza, [2013], Olugu, Wong Kuma, and Shadoroum [2010], Atusa, Guide and Van Wassenhore [2008]. Based on these reverse logistics arrangements, partnerships with various other organizations are developed, products are recycled; costs of production and their incidences are held down, and are not shifted to customers, solid waste management costs and the environmental impact in landfill are reduced, thus economic and ecological dividends are realized-Berkowitz, Kerin, Hartley and Rudelius (2000: 460), Atusa, Guide and Van Wassenhore [2008], Ferguson and Fleischmann, Souza [2011], Galbreth, Boyaci, and Verter [2012] and Atasu, Van Wassenhore and Sarvary [2009].

This work is interested in determining the relative degree of applicability of the concept of reverse logistics in Nigeria, for possible constraints management, as solution to the high level of environmental debasement in Nigeria. 


\subsection{Objectives of the Study}

The objectives of this study include:

To identify factors that are responsible for the poor attitude of manufacturing firms in Nigeria to reverse logistics programmes

- To identify challenges to the implementation of reverse logistic programmes.

- To ascertain whether or not relationships do exist between poor reverse logistics management and environmental debasement in Nigeria; and

- To profer solution to environmental management for sustainability through reverse logistics management.

\subsection{Significance of the Study}

This study with its results will promote environmental consciousness among manufacturers in Nigeria, thus will improve the level of social responsibility as well as public image of the firms. It will also aid the protection of the Nigeria physical environment; and improve the hygiene and health standards of Nigerian urban, sub-urban and rural areas.

\subsection{Hypotheses}

The work is based on three hypotheses stated in Null form

$\mathrm{H}_{1}$ : Inadequacy of governmental policies implementation does not account for inadequacy in the adoption of reverse logistic system among firms.

$\mathrm{HO}_{2}$ : Inadequacy in the adoption of the reverse logistics system among firms does not account for the high level of environmental debasement in Nigeria.

$\mathrm{HO}_{3}$ : There is no significant difference between the rating of manufacturers themselves, and consumers on the impact of inadequate adoption of reverse logistics programmes on the physical environment in Nigeria.

\subsection{Methodology}

For the evaluation; the operations of firms in the food and drink industries were considered important. The activities of sub-elements of these industries-Nigeria Bottling Company Plc and 7 Up Bottling Company Plc as recycle based firms were evaluated in the height of the impact of their recycleable wastes on the physical environment in Nigeria.

\subsection{Organization of the Paper}

This work is organized under eight (8) major sub headings of Abstract, Introduction; Literature review; analysis; findings and discussions; recommendations and conclusions; and references.

\section{Literature Relevant of the Study}

\subsection{Frame Work of the Study}

The Nigeria nation like most African states has difficult and complex environmental challenges; some of which are natural and others caused by natural and artificial persons' economic activities. These include soil loss and deterioration, water and forest degradation, atmospheric pollution and climatic changes as well as species and gene-pool extinction-Papp (1998). Contemporary worst challenging of these, is the poor hygiene and health conditions of most major towns and cities as occasioned by heaps of domestic and industrial wastes; reusable and recyclable materials.

Most governments globally have well established policy based and monitored system of waste management, hence citizens are saved from the hazards of environmental debasements -Atusa, Guide and Van Wassenhore [2008], Guide, Souza and Van Wassenhore [2006], Green, Morton and New [1999], Fleischmann, Beullens, Bloemhof-Ruwaard and Van Wassenhore [2001]. The health standard of these nations is adjudged high thus citizens contribute healthy labour to economic development. The situation in Nigeria is a negation of global standards; hence the growing population is worse off.

By global standard, artificial persons in economic activities like the natural persons are expected to be involved in activities aimed at abating pollution, some of these activities include:

- Installation of modern equipment

- Engineering new facilities for minimum environmental effects

- Research and technological development 
- Cooperation with municipalities in joint treatment facilities

- Cooperation with local, state, regional and federal agencies in developing improved systems of environmental management; and

- Development of more effective programmes for re-cycling and re-using disposable materials-Committee for Economic Development (1971: 38).

This work is interested in determining the impact of inadequacy in the adaption and or adoption of the provisions of this pollution abating policy in Nigeria as a basis for measuring of its impact on the physical environment of Nigeria especially in the light of the expectations of 21 st century consumers on business organizations vis-à-vis social responsibilities; and how reverse logistics activities of firms can be solution to environmental pollution.

\subsection{Environmental Issues of Marketing}

Common environmental issues that attract the interest of marketers are solid waste disposal; air, water and land pollution, resources depletion, chemical additives or harm to nature-Troy (1993: 100-113). Consumers contrary, consider a specific environmental claim to be one that provides detailed, useful information, indicates that the product has environmental benefits superior to competing products and show a clear improvement to the environment-Stafford, Stafford and Chowdhury (1996: 68-70), Blackburn, Guide, Souza and Van Wassenhore [2004], Guide and Van Wassenhore [2004], Guide, Teunter and Van Wassenhore [2003], Padmanabhan, and Png I [1995], Wood [2001] and Plamback, and Wang [2009].

In response to the call for environmental protection, marketers adopt the green marketing approach that has the following as thrust of interest-Hawkins, Best and Coney (2000: 88):

- Producing products whose production, use or disposal is less harmful to the environment than the traditional versions of the product

- Developing products that have positive impact on the environmental, and or,

- Tying the purchase of a product to an environmental organization or event.

- Nigeria as a consumption rather than industrialized economy should be committed to products whose use and disposal is less harmful to the environment, thus is expected to be product recycling oriented and reverse logistics management bias.

To achieve expected environment sustainability rate and standard in Nigeria will require scarifies both of producers and consumers. Thus parties to basic exchange transactions would make special efforts to buy products from companies that protect the environment; give up some convenience for environmentally safer products or packaging and pay more for such products-Hume and Strand (1989: 3) and Ottman (1998: 10).

Green marketing is complex -Hawkins, Best and Coney (2000: 90), as environmental concerns are not only one criteria consumers use in making purchase decisions - Stanly and Lasonde (1996:183-188) and Chan (1996: 43-45) Green, Morton and New [1999], Zhu, Sarki, and Lai [2008], Trowbridge, [2006], Van Ahusen, [2006], Srivastara, [2007], Zhu, Sarkis and Lai [2007], Zhu, Sarkis and Lai [2007].and Spengler, Stolking, and Ploog [2004]. Mobley et al (1995: 165-176) assert that the use of recycled materials generally elicits a possible response from consumers. This may not be the case with other environmental sound actions-Hawkins, Best and Coney (2001-90). Based on the above, firms must balance their concern for the environment with other consumer expectations and financial constraints, considered thus:

The polystyrene container uses 30 percent less energy to produce than does coated paper or paper board and the manufacture results in 40 percent less air pollution and 42 percent water pollution-Mobley at el (1995: 165-176). However, the solid waste problem they create is much more visible to consumers than the air pollution and energy depletion areas in which they create great savings -Hawkins, Best and Coney (2000: 90).

Given these complex decisions issues in environment sustainability management, organizations are in dilemma of environmental conservation and maximization of business strategies. Hence, the basic thrust of environmentalism is the "three R-reduce. reuse and recycle-Hawkins, Best and Coney (2000: 90), "four R-reduction, reuse, recycling, and recovery- http://www.care2.com/c2c/share/detail/246651. and 5 steps of waste hierarchy-prevention, preparing for reuse, recycling other recovery and disposal- Directive 2008/98/EC. The management of this thrust of environmentalism determines the sustainability of the future economic and environmental situation of Nigeria as a developing nation-Zinkhan and Carlson (1995: 1-6) and Kilbourne (1995: 7-19). 


\subsection{Product Disposition-Marketing Implications}

The desire to minimize the cumulative impact of industrial and domestic consumer wastes on the quality of the physical environment and the lives of current and future generations calls for increasing concern for proper disposition of used products, (wastes) as residuals.

Four major ways in which disposition decisions can affect a firm's marketing policies, decisions and strategies in the assertion of Hawkins, Best and Coney (2000: 637) are:

- Disposition sometimes must occur before acquisition of a replacement because of physical space or financial limitations.

- Frequent decisions by the consumer to sell, trade or give away used products may result in a large used product market that can reduce the market for new products.

- It influences the consumers re-peat purchase decision; and

- Environmentally sound disposition decisions benefit society as a whole and thus, the firms that are part of that society.

Given the above, the call for the development of products, packages and programmes that encourage proper disposition decisions especially based on recycling and reverse logistics management is considered imperative for Nigeria.

In Nigeria, especially in the urban and semi-urban areas, domestic and industrial wastes litter the cities. The management of these wastes provides employment opportunities for individuals and corporate bodies. Yet little or nothing reasonable, over the years have been achieved as the environmental conditions of the cities continue to de-generate and personal living conditions of the employees of waste management system leave nothing to be desired.

The improvised state of the Nigeria waste management system demands attention especially in respect to disposition of products. Attention should also be focused at the management of dioxins, lead and mercury. Emphases should be on the use of packages that require nominal amount of resources given their obvious economic benefits and inclination to social responsibility as such containers should be recyclable or re-useable.

Marketing activities contemporarily and in the future should discourage "throw it away" as an alternative to proper disposition of product containers and packages; as such, emphasis should be on reverse logistics management as strategic alternative to environmental sustainability in Nigeria.

\subsection{Reverse Logistics Management}

Disposition of the product or the product containers may occur before, during or after product use-Hawkins, Best and Coney (2000: 635). Identification of proper disposition points and effective execution of the disposition action save; the environment in terms of littering; the government in terms of cost of policing the area with environmental agencies and the business organizations in terms of collecting and dumping of refuse and land filling of waste pits. These costs saving benefits to the business organizations have the ability of positioning producers to satisfy the consumers at higher profit margin based on enhanced turnover and consumer loyality.

Product disposition objectives will however remain elusive in Nigeria without effective reverse logistics management strategies. Reverse (logistics management) distribution is the movement of broken, unwanted or excess products returned by the consumer or resellers-Kotler and Armstrong [2006: 379], French, and LaForge [2006] and Fleischmann, Galbreth and Tagaras (2010). It is also a process of reclaiming, recyclable and reusable materials, returns and reworks from the point of consumption or use for repair, remanufacturing or disposal-Berkowitz, Kerin, Hartley and Rudelius (2000: 460).

Organizations involved in the adoption of the reverse logistics strategies are expected to attach equal relevance to the out bound distribution (movement of products from the factory to re-sellers and ultimately to customers), inbound distribution (moving products and materials from suppliers to factory) and reverse distribution (moving broken, unwanted or excess products returned by consumers or resellers)-Kotler and Armstrong (2006: 379), Olugu, Wong Kuam and Shadaroum [2010]. These processes are considered the bane of total logistics management, as upstream and downstream flows add value in aggregate, to satisfy the firm, the consumers and the environment at profit for sustainable future-Atasu, Van Wassenhore and Sarvary [2009] and Andel and Archlmayr [2002]. 


\subsection{Reverse Logistics Activities}

Reverse logistics activities whether internal department managed or based on third party experts, should ensure efficient and steady flow of material in and waste in reverse order into the business-Fleischman (2004), Green, Morton and New [1999]. The decision in favour of either or a combination of the management option is influenced by the expected effect of the system on corporate operation; like control of distribution system in relation to the marketing intermediaries' activities, control of price of product, quality of product (adulteration) and the promotional expenditure. Hence the transportation and technical facilities must be up dated in relation with characteristics of the market and the type and amount of residue-Kelchner (2012), Ferguson, Guide and Souza [2006].

Generally, for efficiency in reverse logistics activities, the final consumer at the industrial or household point is considered first collection step as waste (for re-cycle and or pre-cycle) are collected in small -easy-to-carry containers that are moved in vessels to the central collection sites -Guide, Souza and Van Wassenhore[2006] and Kwak and Kim [2013]. This however, is influenced by the volume of waste, as the pick-up system; that considers high volume of residues could also be adopted. In both cases, considerations are made for manual ease of use and technical handling systems.

Equipment for reverse logistics could be residue compaction or multi-chamber vehicles-Fleischman (2004), Ferguson, Guide and Souza [2006], with varying comparative advantages influenced by corporate objectives and philosophies.

\subsection{Cost Implications: Reverse and Non-Reverse Logistic Based Products}

In the soft drink industry in Nigeria, selected companies have their products in bottles, plastic or and metallic cans.

The cost implications of these products at the consumer level are shown thus:

All flavours of Nigerian Bottling Company Plc product

- Bottle; per unit selling price at consumer level is $\$ 60.00$

- Plastic and Metallic cans; per unit selling price at consumer level is $\$ 100.00$

- Content per bottled product is $35 \mathrm{cl}$

- Content per canned product is $33 \mathrm{cl}$

- Content of the bottled product is bigger than canned product.

- Price differential between bottled product and canned product is $\$ 40.00$

- It means that though the bottled product has higher volume of liquid content compared to the canned, the canned product is sold 40.00 or more above the price of bottled product, especially, considering that the producers re-cycle the bottles.

Both packaged products (bottle and can) have the same quality and pass through the same production process, and the same logistics of distribution and promotion.

The bottled products of both Nigeria Bottling Company Plc and 7Up Nigeria Bottling Company Plc are scheduled for and are managed under reverse logistic system, thus the empty bottles are returned to the production plants at no cost to the consumers. This is based on the fact that return logistics of the product takecare of the residues (empty bottles). This accounts for why empty bottles of Nigeria Bottling Company Plc and 7Up Bottling Company Plc products as well as those of the alcoholic industry of Nigeria Brewery Plc and Guinness Nigeria Plc do not litter the physical environment in Nigeria.

Contrary to the sinero above, the same companies like producers of Amstel Malt, Malta Guinness, Maltina, Grand Malt among others have their residues as aluminum cans and plastic containers littering the environment and contributing significantly to the debasement of environmental standard of Nigeria. Though no price differential exist between the price of alcoholic bottled and aluminum and plastic canned drinks at the consumer point, the price differential between the bottled and aluminum and plastic canned products is put at $\$ 40.00$ and \$50.00 respectively for Nigerian Bottling Company Plc and 7Up Bottling Nigeria Plc-non alcoholic drinks. The researchers would want to know if the empty cans as residues are worth $\$ 40.00$ and $\$ 50.00$ for the respective companies even when consumers pay above $\$ 40.00$ for each empty plastic and aluminum cans.

Considering the price differential between the bottled and canned products (aluminum or plastic), put at $\$ 40.00$ and $\$ 50.00$ respectively for Nigeria Bottling Company Plc and 7 Up Nigeria Bottling Company Plc. In average, 
both companies charge Nigerian consumers as much as $\$ 45.00$ per empty aluminum and plastic can for what these producers refer to "convenience of package and product usage". The research would want to know if the empty containers in aluminum and or plastic as residues are worth $\$ 40.00$ and $\$ 50.00$ for the respective companies and if not, does the price not amount to exploiting the market, especially considering the environmental nuisance of the value of the residuals.

Assume that both the Nigeria Bottling Company Plc and 7 Up Nigeria Bottling Company Plc as market leaders in the soft drink industry have a turn over 140 Million Units of aluminum and plastic canned products are consumed per annum in Nigeria, these companies must have exploited the Nigerian market to the tune of 5.6 Billion Naira for soft drinks and littered the environment with 140 Million empty aluminum and plastic cans excluding fayroux, Amstel Malt, Malta Guinness, Maltina and Grand Malt, whose consumption rate is estimated to be high among the Christian communities and high income earning class of Nigeria and Nigeria Brewery Plc and Guinness Nigeria Plc as leaders in the alcoholic drink industry have turnover of over 654 Million aluminum cans of Guinness Stout, Harp, Star, Gulder and Heineken Lager beer. You could imagine what the situation will be over in a period of 10 years.

In some developed societies unlike in Nigeria, firms either by direct management of reverse logistics programmes or based on third - party logistics providers service arrangement have managed wastes in the photographic, computer and printer toner cartridges and lead-acid batteries for automobiles and boats industries respectively, hence have sustained environmental stability programmes- Bartholomew Doug (1998)-Agrawal, Atasu and Van Ittersum [2012].

Reverse logistics functions of transportation, warehousing, packaging among others are principal chain contributors to corporate environmental sustainability effort. They also save cost for enhanced corporate profitability-Kotler and Armstrong (2010: 381), Souza [2013], Atasu, Guide and Van Wassenhore [2008] and Guide, Van Wassenhore and Sarvary [2006]. The cost saved given reverse logistics functions are re-invested in environmental sustainability drive through re-cycling of waste in some developed societies like UK and Sweden -Hoffman (2008)-Souza [2013] and Zikopoulos and Tagaras [2008]. Reverse logistic with particular reference to waste management offers both economic and ecological dividends. These dividends are emphasized by Berkowitz, Kerin, Hartley and Rudelius (2000: 460) thus:

"By recycling 90 percent of the lead firm used batteries, manufacturers have kept demand for new lead in check, thereby holding down costs to consumers. Also, solid waste management costs and environmental impact of lead in landfills is reduced."

The reverse-flow channels (Reverse Logistics) are especially considered important because of the following:

- It offers manufacturers the opportunity of re-using products or containers-such as re-fillable channel-carrying drums carneras.

- Products are refurbished for re-sale especially in, computers and circuit boards.

- Products as papers are recycled, and

- Products and packages as waste are disposed -Kotler and Keller (2009: 457).

Conventionally product and users in some developed and developing economies such as community groups are traditional intermediaries in addition to the manufacturers in association with their redemption centres and third party agents such as trash collection specialists, recycling centres, trash-recycling brokers and central processing warehousing are participants in reverse logistic management-Jahre (1995) -Atasu, Guide and Van Wassenhore [2008], Olugu, Wong Kuam and Shadorum [2010] and Zukopoulos and Tagaras [2008].

The study's concern is on why most manufacturing firms in Nigeria are not reverse logistics management oriented in plans and policies. At Victoria Island-Lagos; Calabar and some parts of Enugu metropolis in Nigeria, where policies of environmental management are in place, the programmes are executed at the cost to the consumers and are inefficiently carried out.

\subsection{Logistics Management in Nigeria-Food and Drink Industries}

Logistics management in the food and drink industries is conventional in Nigeria, as in most other economies; however the defect is in the area of reverse logistics for end users wastes for re-use and recycling of aluminum and plastic packaged products.

Firms in the food and drink industries move their products to the consumers through Depot (dealers-wholesalers and distributors), to retailers as organized or un-organised end users service points. For depot (dealers-wholesales or distributors) to qualify to be enlisted in this logistics programmes, the firms as natural or 
artificial persons must have acquired empty drinks bottles and empty drinks crates as primary and secondary package requirements respectively. Thus the amount of these empties must match the firm's desired carrying capacity. Thus dealers down to the end users service point have and own empty bottles and crates.

Thus on payment for the drinks at the depots, the end-users server drops the empty bottles and crates equivalent of what it is buying. The depot returns same to the producers for a re-supply. Based on this arrangement $99 \%$ of the bottles and empty crates released by the producers are returned in situations where leakage in return of empties occur, it is traced to the point of leakage and the leakage is paid for as a condition to remain a member of the distribution and reverse distribution channel.

This system is however limited to bottle like products in the food and drink industries. The food and drink producing firms do not have any programme of reverse logistics for aluminum and plastic canned food and drink. They do not commission agents to retrieve the empty aluminum and plastic cans. This accounts for the numerous and huge heaps of these wastes in different towns and streets of the 36 states of Nigeria including the capital city Abuja. The environmental impact of these wastes is the concern of this work.

The consumers do not play any role in the re-use or recycling of aluminum and plastic cans based on take-back policy unlike in the bottle packages of these food and drink industries because no condition is attached to purchases and use of the product unlike that of the bottled product where you need to present an empty bottle before you can take home the bottled product.

Based on the management of bottled product reverse logistics programme, the producers, the dealers, the organized and un-organized end-users service centres and the end-users are actors, as incentives are attached that encouraged (return of bottles) take back policy. This incentive is absent given aluminum and plastic canned products, hence the consequent -failure in the products reverse logistics activities.

\section{Analysis and Test of Hypotheses}

Copies of questionnaires were administered on two market leaders in the soft drink, non-alcoholic malt drink and alcoholic drink industries as well as those of the food and confectionery industry, two major distributors of these products were carefully selected from each of the six geo-political zones of the (country) market and 20 (twenty) consumers from each of the 36 (thirty six) states of the country. Special attention was given to the special characteristics of the marketing intermediaries and consumers as Christians, Muslims and indifference in religious background and inclination.

These questionnaires addressed various variables considered vital for success in the practice of reverse logistic management and impact of poor waste management system on the physical environment-Committee for Economic Development (1971: 38). Consumers of products of these selected firms were asked questions based on scheduled interview to uncover issues that were not addressed given the sets of questionnaires.

Results of analyses are in tables 1, 2, 3, 4, 5 and 6; these formed the basis of test of hypotheses thus:

Table 1. Opinions of respondents, subject to research questions

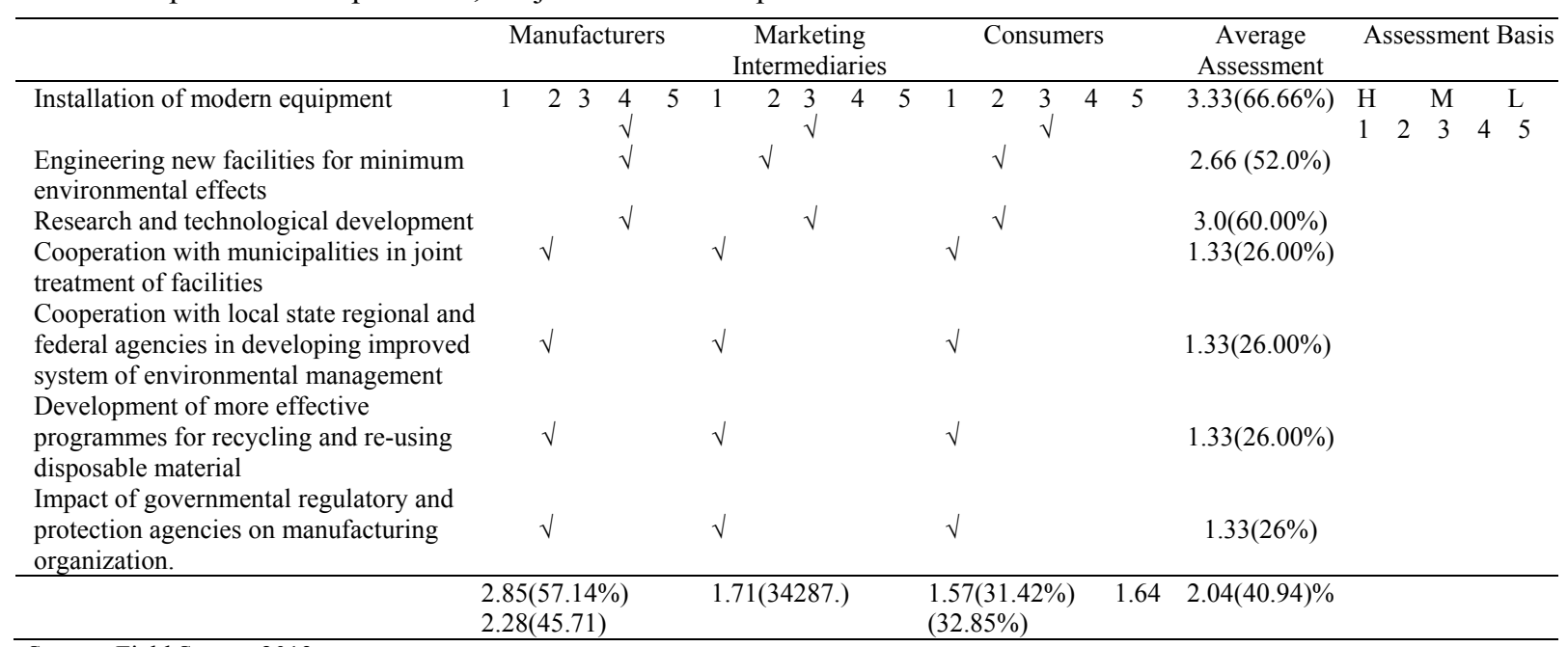

Source: Field Survey 2013.

Note: scales 1, 2, 3, 4 and 5 represent $20 \%, 40 \%, 60 \%, 80 \%$ and $100 \%$ efficiency level respectively. 
Table 2. Required computation for calculating rxy

\begin{tabular}{|c|c|c|c|c|c|c|c|}
\hline Variables & $\begin{array}{l}\text { Manufacturers and } \\
\text { Marketing } \\
\text { Intermediaries (x) }\end{array}$ & $\begin{array}{l}\text { Consumers and } \\
\text { Marketing } \\
\text { Intermediaries (y) }\end{array}$ & $x-0$ & $(x-0) 2$ & $y-\bar{y}$ & $(y-\bar{y}) 2$ & $(x-0)$ \\
\hline 1 & 7 & 6 & 2.43 & 5.90 & 2.72 & 7.39 & 6.60 \\
\hline 2 & 6 & 4 & 1.43 & 2.04 & 0.72 & 0.56 & 1.02 \\
\hline 3 & 7 & 5 & 2.43 & 5.90 & 1.72 & 2.95 & 4.17 \\
\hline 4 & 3 & 2 & -1.57 & 2.46 & -1.28 & 1.63 & 2.00 \\
\hline 5 & 3 & 2 & -1.57 & 2.46 & -1.28 & 1.63 & 2.00 \\
\hline 6 & 3 & 2 & -1.57 & 2.46 & -128 & 1.63 & 2.00 \\
\hline \multirow[t]{2}{*}{7} & 3 & 2 & -1.57 & 2.46 & -128 & 1.63 & 2.00 \\
\hline & $\Sigma x=32$ & $\Sigma y=23$ & \multicolumn{2}{|c|}{$\Sigma(\mathrm{x}-0)=23.68$} & \multicolumn{2}{|c|}{$\Sigma(y-\bar{y})=19.98$} & $\Sigma(\mathrm{x}-0)(\mathrm{y}-\overline{\mathrm{y}})=19.79$ \\
\hline
\end{tabular}

Table 3. Opinion rating of respondent's on governmental policies and adoption of reverse logistics programmes

\begin{tabular}{cccc}
\hline Variables Considered & Assessment by Manufacturers & Assessment Intermediaries & Assessment by Consumers \\
\hline 1 & 4 & 3 & 3 \\
2 & 4 & 2 & 2 \\
3 & 4 & 3 & 2 \\
4 & 2 & 1 & 1 \\
5 & 2 & 1 & 1 \\
6 & 2 & 1 & 1 \\
7 & 2 & 1 & 1 \\
\hline
\end{tabular}

Table 4. Rating of the impact inadequacy of the adoption of reverse logistics system among firms on the physical environment

\begin{tabular}{cccc}
\hline Variables Considered & Assessment by Manufacturers & Assessment Intermediaries & Assessment by Consumers \\
\hline 1 & 3 & 3 & 2 \\
2 & 4 & 2 & 2 \\
3 & 4 & 2 & 2 \\
4 & 2 & 1 & 1 \\
5 & 1 & 1 & 2 \\
6 & 2 & 1 & 2 \\
7 & 2 & 1 & 2 \\
\hline
\end{tabular}

Table 5. Rating of impact of non adoption of reverse logistic by manufacturers on the physical environment

\begin{tabular}{|c|c|c|c|c|c|}
\hline \multicolumn{2}{|c|}{ Manufacturers } & \multicolumn{2}{|c|}{ Marketing Intermediaries } & \multicolumn{2}{|r|}{ Consumers } \\
\hline $\mathrm{XA}$ & $\mathrm{X}^{2} \mathrm{~A}$ & $\mathrm{XB}$ & $\mathrm{X}^{2} \mathrm{~B}$ & $\mathrm{XC}$ & $\mathrm{X}^{2} \mathrm{C}$ \\
\hline 4 & 16 & 3 & 9 & 3 & 9 \\
\hline 4 & 16 & 2 & 4 & 2 & 4 \\
\hline 4 & 16 & 3 & 9 & 2 & 4 \\
\hline 2 & 4 & 1 & 1 & 1 & 1 \\
\hline 2 & 4 & 1 & 1 & 1 & 1 \\
\hline 2 & 4 & 1 & 1 & 1 & 1 \\
\hline 2 & 4 & 1 & 1 & 1 & 1 \\
\hline$\Sigma x A=24$ & $\Sigma \times 2 A=48$ & $\Sigma \mathrm{xB}=12$ & $\Sigma \times 2=26$ & $\Sigma \mathrm{xc}=1$ & $\Sigma \times 2 c=21$ \\
\hline \multicolumn{2}{|c|}{$0 \mathrm{~A}=3.42$} & \multicolumn{2}{|c|}{$\mathrm{OB}=1.71$} & \multicolumn{2}{|c|}{$0 \mathrm{C}=1.57$} \\
\hline \multicolumn{2}{|c|}{$\mathrm{n}=7$} & \multicolumn{2}{|c|}{$\mathrm{n}=7$} & \multicolumn{2}{|c|}{$\mathrm{n}=7$} \\
\hline
\end{tabular}

Table 6. Summary of ANOVA

\begin{tabular}{cccccccc}
\hline Sources of variation & df & $\begin{array}{c}\text { Sum of } \\
\text { sequences ss }\end{array}$ & $\begin{array}{c}\text { Mean of sequences } \\
(\mathrm{ms})\end{array}$ & f. cal & $\begin{array}{c}\text { Critical value } \\
\text { of } \mathrm{f}\end{array}$ & Significance & Decision \\
\hline Between groups & 2 & $\mathrm{SSB} 14.84$ & $\mathrm{VB} 7.42$ & & & & Accept H1 \\
Within groups & 21 & $\mathrm{SSW}=25.06$ & $\mathrm{Vw}=-1.253$ & 5.93 & 3.89 & Significant & A \\
Total & 23 & -10.22 & -6.17 & & & & \\
\hline
\end{tabular}




\subsection{Hypotheses 1 and II}

$\mathrm{HO}_{1}$ : Inadequacy of government policies implementation does not account for inadequacy in the adoption of reverse logistics system among firms.

$\mathrm{H}_{2}$ : Inadequacy in the adoption of the reverse logistics system among firms does not account for the high level of environmental debasement in Nigeria.

Adopting the Pearson Correlation Co-efficient R

$$
r_{x y}=\frac{\sum(x-0)(y-\exists)}{n S x \text { Sy }}
$$

Where: $\mathrm{x}$ and $\mathrm{y}$ are each values of $\mathrm{x}$ and $\mathrm{y}$

0 and $\exists$ are mean values of $x$ and $y$

$\mathrm{S}_{\mathrm{x}}$ and $\mathrm{S}_{\mathrm{y}}$ are standard deviations of $\mathrm{x}$ and $\mathrm{y}$

$\mathrm{n}$ is the number of paired values

Source: Ezejelue AC, Ogwo E.O and Nkamnebe A.D (2008), Basic Principles in Managing Research Projects. Aba -Nigeria, Afritower Limited.

\subsubsection{Hypothesis I}

Substituting for statistical notation (1) based on table $3 ; \mathrm{r}$ xy $2=0.753$, showing a positive correlation between assessment of manufacturers and marketing intermediaries as $\mathrm{x}$ variable and consumers and marketing intermediaries as y variables on the impact of inadequacy of government policies implementation on the adoption of reverse logistic system.

\section{Decision:}

The value of the ' $t$ ' computation is 8.06 ; this is at .05 level of significance, with 5 degrees of freedom (7-2). The critical value of the' $t$ ' statistics is given as 2.004. This is significant, thus the null hypothesis is rejected. Accepted is inadequacy of government policies implementation accounts for inadequacy in the adoption of reverse logistics system among firms.

\subsubsection{Hypothesis II}

Substituting for statistical notation (1), based on table 4; rxy2 $=0.789$, showing a positive correlation between assessment of manufacturers and marketing intermediaries as $\mathrm{x}$ variable and consumers and marketing intermediaries as $y$ variable on the adoption efficiency or otherwise by firms, of reverse logistics as factor variable on environmental debasement.

Test for significance of the correlation is based on students' $t$ ' test statistical notation:

To conduct this test, the hypothesis is re-structured thus:

$$
\mathrm{t}=\frac{r / n-2}{1-r}
$$

Where $r=$ the value of Pearson Correlation

$\mathrm{n}=$ the number of paired observations.

$\mathrm{HO}_{2}: \mathrm{R}=0$ (there is a linear relationship between $\mathrm{x}$ and $\mathrm{y}$.

$\mathrm{H1}_{2}$ : $\mathrm{E}=0$ (there is no linear relationship between $\mathrm{x}$ and $\mathrm{y}$.

Source: Ezejelue AC, Ogwo E.O and Nkamnebe A.D (2008), Basic Principles in Managing Research Projects. Aba- Nigeria, Afritower Limited.

Substituting for statistical notation (2), based on calculation, given statistical notation $1, t=8.22$

\section{Decision:}

The value of the ' $t$ ' computation is 8.22 , this is at 0.05 level of significance, with 5 degrees of freedom (7-2). The critical value of the $t$ statistics is given as 2.015. This is significant, thus the null hypothesis is rejected. Accepted is inadequacy in the adoption of the reverse logistics system among firms accounts for the high level of environmental debasement in Nigeria. 


\subsection{Test of Hypothesis III}

There is no significant different between the rating of manufacturers (themselves) and consumers on the impact of inadequate adoption of reverse logistics programmes on the physical environment in Nigeria.

Test of Hypothesis III, the Hypothesis is restructured thus:

$\mathbf{H O}_{2}$ : $(\square 1=\square 2=\square 3)$ there is no significant difference between the rating of manufacturers (themselves) marketing intermediaries and consumers of the impact of inadequate adoption of reverse logistics programmes on the physical environment in Nigeria.

H1 $_{2}:(\neg 1 \neq * * \square 2=\square 3)$ significant difference exists between the rating of manufacturers (themselves) marketing intermediaries and consumers on the impact of inadequate adoption of reverse logistics programmes on the physical environment in Nigeria.

Where: $\square 1 \square 2$ and $\square 3$ are mean of the rating of the three groups of respondents.

$$
\text { Given: } f=\frac{v_{b}}{v_{w}}=\frac{\text { between groups variance }}{\text { within groups variance }}=\frac{B_{B}^{2}}{S_{w}^{2}}
$$

Where: $V_{B}=\frac{S S B}{d f_{B}}$ and $V_{w}=\frac{S S W}{d f_{w}}$

Source: Ezejelue AC, Ogwo E.O and Nkamnebe A.D (2008), Basic Principles in Managing Research Projects. Aba -Nigeria, Afritower Limited.

Computation of $f$ ratio: based on data on table 6 , and substituting for statistical notation $3 \mathrm{f}$ ratio is 5.936 .

Summary of ANONA on table 6 shows that at 0.05 level of significance, the critical value of $f$ is given as 3.89 . Since $\mathrm{f}>\mathrm{f} 0.05$ (3.89), $\mathrm{H} 0$ is rejected, and the conclusion is that there is significant difference between the rating of manufacturers themselves and consumers on the impact of inadequate adoption of reverse logistics programme on the physical environment in Nigeria.

\subsection{Remark / Interpretation of Hypotheses}

Based on the hypotheses as analyzed, the inadequate adoption of reverse logistics management policies by firms is directly responsible for the debasement of physical environment in Nigeria. It is also important to note that manufacturers do not have good evaluation of the impact of their deficit policies in reverse logistics on the environment. This is attributed to the non-adoption of market concept principles, policies and strategies, especially the paucity of corporate research effort at determining the needs and wants of the target market. It is obviously correct to assert that firms in the food and drink industries are more inclined to selling concept of sell more stuff to more people more often for more money in order to make more profit-Newman (1999) and Newman (1999).

\section{Findings}

The research work has the following as key findings

- Firms in the food, and drink industries are marketing concept oriented only to the extent that modern equipment are acquired and research and technological developments are considered areas of investment. These firms are neither market (marketing) sustainability oriented (health and life of consumers are not given principal attention) nor environmental friendly, thus, are not green marketing focused; hence they are not socially responsible.

- The firms in these industries do not provide old nor new engineering technology or facilities to ensure minimum environmental impact of their waste, disposable and reverse logistics based items on the physical environment of Nigeria.

- These firms do not have any form of cooperation with municipal authorities on joint treatment of facilities nor do they cooperate with local, state, regional and federal agencies for the purpose of developing improved system of environmental management.

- These firms in the food and drink industries respectively are not committed totally to programmes of re-cycling and re-using of disposed materials. Programme activities in this area are related to reverse logistics in bottle related and-user disposal material(s) only, thus aluminum and plastic related containers for soft drink and 
alcohol as well as food items and polythene packages and containerization items are not reverse logistic based, thus these items are not re-cycled nor re-used, hence they litter the environment.

- Firms in these industries are not under the effective control and supervision of governmental agencies charged with the responsibilities of environmental protection as obtainable in some advanced economies.

- Consumerism activities in Nigeria are at its lowest ebb compared to most nations of the world, thus these firms are not under any threat to be environmentally friendly.

- The situation in Nigeria is traceable to the high level of poverty, illiteracy and non responsive attitude of government to national issues. Hence firms in these industries are taking advantage of the situation.

The firms before, during and after production of most products do not conduct environmental impact assessment of their market offer, thus do not observe that cans, plastic containers and polythene packages as associates and disposable (waste) items of their market offer constitute environment nuisances and pollutants.

\subsection{Discussion of Findings}

- The findings of this work agrees with the observed heaps of industrial re-usable and recycle-able disposals found in most parts of major streets of the towns in Nigeria. These heaps in addition to their pollutant effects constitute environmental nuisance, and a disservice to marketing, as the health standard of the target market is subject to jeopardy.

- Firms in the food and drink industries move their products in bottles, aluminum and plastic containers and polythene packages. At the end of the distribution channel, deliberate policies are planned and executed to ensure that bottles and not aluminum and plastic containers are returned for re-use and re-cycling. This situation has prevailed because the agencies charged with environmental protection and control do not exercise authority over these corporate bodies. The cost per aluminum and or plastic container of product as waste re-usable or recycleable is little compared to what consumers pay for the aluminum /plastic container. Example, a bottle of coke is sold at $\$ 60.00$ while the aluminum plastic is sold at $\$ 100.00$; the consumers are unaware of their rights to demand for quality in product and environmental cleanliness as basis of exchange relationship (consumerism), as it is currently in the metal industry (scrap).

- In Nigeria between the 1980's and 1990's, firms in the food and drink industries commissioned agents called "Ndi ololo" in the eastern, "asago" "and "asabata" in the western and "bola" in the northern parts of the country respectively who pick the bottles and aluminum packages and disposal (waste) for re-use and re-cycle. This system formed a primary level of reverse logistics and in addition to reducing cost of operation aided the reduction of waste on the physical environment. Food and drink producing companies are no more in this business of reverse-logistics especially for aluminum and plastic packages.

- In the developed societies-Japan, for example unlike in Nigeria, the coca cola company in major streets provides waste bins for the collection of aluminum and plastic packages and pay consumers rebates for each returned aluminum/plastic as a reverse logistics activity and super markets discourage the regular use of polythene shopping bags as an environmental protection effort, but in Nigeria, in the banking industry, like in the retail outfits, the use polythene bags (package) is adopted for customer service, public relations activities and corporate image building and sustenance and for cash dispensing.

- Most of the firms on their aluminum and plastic containers have remarks that encourage consumers to environmental cleanliness. Such remarks include "Keep the Nation Clean". It is worthy noting that these firms do not provide waste bins where the wastes could be deposited nor do they have reverse logistics programmes that encourage the actualization of the closed loop supply chain objectives.

- It is dis-heartening to observe that most of the firms that operate under this unfriendly customer philosophy are multi-national companies, who are aware of global standards on waste management and reverse logistics management, but are not willing to observe these standards in Nigeria.

\subsection{Actualized Research Objectives}

The research, based on data analysis, traces the poor attitude of manufacturing firms in Nigeria to reverse logistics programme to the following:

- Inactive nature of the Nigerian society especially to the demands for their rights as consumers consequent to low level of literacy. Hence environmentally sound disposition decisions that benefit the society are not considered needful by the firms. 
- Poor attitude of and lack of dedicated leadership among the consumer groups exist, hence the few attempts at consumer education are not sustained.

- High rate of non-responsiveness of government through its environmental protection agencies to the duty of environmental care in Nigeria. Though there exist an array of laws, regulations and protocols on environmental protection, governments lack the inertia to bring defaulters to book.

Based on the aforrnamed, the firms in the food and drink industries especially, who are mostly multi-national in operation are not reverse logistics management policies and strategies oriented. Hence the littering of the environment with residues (wastes) in aluminum cans and plastic packages.

\subsection{Challenges to Implementation of Reverse Logistics}

Common challenges to the implementation of reverse logistics programme in Nigeria are both cultural; system based and technology oriented hence are society (market) and producers anchored. These are highlighted thus:

\section{- Lack of environmental sanitation and cleanliness culture among vast number of Nigerian consumers}

Products are consumed and the packages as residuals are carelessly disposed even along the streets without recourse to provided bins. This cultural defect negates the take-back policy as the end users do not return product. This culture makes the role of collection agents non-feasible. This practice is also common in some of the advanced economies of the world, however with, varying degree of compliance between nations and industrial and domestic items of usage-Olugu, Yew Wong and Shaharoun [2010].

\section{- Un-organized Eating and Feeding Habit}

Common to Nigerians is the practice of un-organized eating and feeding as consumers who are in a hurry to eat are less likely to attend to proper disposal of residues than those who have extra time-Hawkins, Best and Coney (2001: 296). Restaurants and other officially approved eating centres are common features of the society. These are not patronized, rather food hawkers, as most consumers do not afford the services of organized eating centres given the low per capita income. Hence collection of waste (residues) is difficult. The nation has degenerated and deteriorated into one with a cherished "throw-away culture-Okpara (2002: 541), thus, if we are to effectively protect our environment, the majority of Nigerians would have to be re-educated to change their misconception that the rest of the world outside their home or car is a universal garbage dump-Falomo (1997:114) in Okpara (2002: 547).

\section{- Psychology of Buying}

The smaller number of consumers whose aggregate income is considered higher, see metallic and plastic canned products as symbolic. The high patronage for these products evokes emulation by the lower income earners. Summarily, Nigerian consumers are psychographically consumption oriented, thus do not acquire products simply but for more complex reasons just as diversion from routine activities, exercise, sensory stimulation, social interactions learning about new trends, and even acquiring for shopping-Westbrook and Black-(1985). Though the relative importance of these psychographic motive of buying canned (metallic or plastic) products rather than bottled vary both across individual and communities (and social classes) and within individual and communities (and social classes) over time as the situation (especially level of awareness) changes-Eastlick and Feinberg (1994: 37-44; 1994: 1-3 and 1996: 52-58). Thus the management of reverse logistics in the food and drink industries in Nigeria is challenged by the management of the psychographic motives of buying of the consumers.

\section{- Lack of Disciplined Leadership}

In few cities of Nigeria-Lagos and Calabar, waste management activities of government are commendable. Leaderships as represented by governments make it a punishable offence to litter the environment, thus the few firms involved in reverse logistics management have collection centres where residues are dropped for collection by the firms. This as practiced in Lagos and Calabar is not tenable in other states. This work is of the opinion that lack of good quality societal leadership on environmental management is a challenge to reverse logistic management in Nigeria.

\section{- The Monopolist Nature of the Nigeria Food and Drink Industries}

The food and drink industries in Nigeria are more of oligopoly in structure compared to competitive market structure, thus the few firms take decision relative to the re-action of others. Hence protecting and sustaining the environment as activities related to economic and social development as hub of closed-loop supply chain management are not considered vital. It is also observed that the prices of the products of these companies that 
cover the cost of the package are high compared to the associate benefits of re-use of packages. Hence reverse logistics activities for these packages reduce already acquired profits of these companies.

These companies are under no law to dispose wastes, thus the cost associated with disposal of waste and acquisition of landfills is zero, thus exploiting economically viable alternative to waste management is not considered an option.

These firms are not interested in reducing the green house effect and global warming generally, thus are not concerned in reverse logistics management neither on whether or how the public burns their waste as a waste management alterative strategy.

Other factors responsible for the nation's poor environmental condition attributable to poor reverse logistics management are:

- Increasing concentration/ density of the population

- Rapid development of new technology and

- The rise and fall in economic affluence-Okpara 2002: 545), as well as increasing dependency on imported products.

Following the observations of this research exercise, it is certain that there is a positive relationship between poor reverse logistics management among firms in the food and drink industries especially those in the bottling and brewery industries and environmental debasement in Nigeria.

\section{Recommendations}

For enhanced environmental sanitation standard and quality customer satisfaction, firms in Nigeria must be reverse logistics management focused in principle and practice, hence should adopt the use of independent "separate" firms to manage their reverse logistics activities or integrate the activities as part of their routine corporate activities. The option adopted however, influences the method and strategy of waste collection, the technological equipment required and the transportation options

The reverse logistics activities should be mixed collection and or separated collection of residues focused, especially as residues are separated at various stages of the reverse logistic channel. With separated collection, especially at the waste sites, residues are relatively unadulterated but where the mixed collection policy is adopted, greater degree of sorting and handling are required which increase cost, especially in warehousing, transportation and handling processes but offers reduction in space needed for the collection containers as just one container will be required.

Firms in the food and drinks industries in Nigeria as a matter of necessity especially for the purpose of actualizing the goal of reverse logistics management must develop and sustain good relationship with the waste producers (consumers of their respective products) as a means of encouraging the consumers to be willing to be involved in the waste disposal activities. This relationship is considered important whether the firms have the choice of the pick up system (from picking up the residues at the site where they are produced) or the delivery system (the producer of the residues or waste collects the residues and takes them to a central area or re-cycling centre.)

Firms in the food and drink industries should adopt the use of current technologies with special features and programmes for re-cycling and re-using disposables especially in the areas of residues collection and transportation. These will be influenced by the type, amount and volume of residues generated; the choice of separated or mixed collection strategy alternatives, and the desire to have containers that are compatible with the respective technical equipment of the vehicles of logistics.

These firms as part of their efforts at being socially responsible, environmentally friendly and sustainable market (marketing) oriented, must strive at creating and sustaining worth while relationships with governments at various levels of authority for environment management and environmental management facilities treatment as well as for the development of improved system of environmental management.

Government through the different consumer and environmental protection agencies should compel the firms to educate the consumers on the cost and environmental hazard implications of consumption of aluminum and plastic packages products compared to bottle. This is in line with what is obtainable in the tobacco industry where consumers are told that "Smokers are liable to die young". This will show the "bottle" as a better alternative to aluminum and plastic packaging and hence reduce the consumption rate of aluminum and plastic packaged products for reduced impact of the residues on the physical environment. 
The citizens of Nigeria should insist that government and its agencies should provide rules for the firms in the food and drink industries and monitor their implementation and in dealing and deciding cases, should be firm, fair and uncompromising-Uzoma (2000:279). The firms in response to this will be reverse logistics responsive.

Generally, consumers should be educated on their right to demand healthy environment and for firms in these industries to be compelled to plough back part of their annual profit on environmental protection through sponsorship of organizations and programmes involved in environmental management. The firms could also device deliberate policies of job creation as people are paid out of the differential between the bottled and aluminum and plastic canned products for the collection of wastes as starting point of the reverse logistics activities. This will achieve the reduction of number and size of heaps of waste sites in Nigeria as well as ensure healthy social and economic environment as employments are created and generated.

The advantages associated with recycling of industrial and or end user wastes compared to cost of disposal of waste through acquisition of landfills is high, these include utilization of less energy and turning out less pollutants; less emission of carbon dioxide based on increased net emission savings; enhanced reduction in green house gas effect and general global warming and enhancing of industrial ecosystem, improvement in environmental performance and productivity at lower cost of operation. This is in addition to information exchange enhancement for environmental regulation -Atasu, Guide and Van Wassenhore [2008], Hervani, Hetms, Sarkis (2005) Ras, (2002), International Solid Waste Association (ISWA) (2003), Tsoulfas, and Pappis (2008) and Beasmom, (2008).

Authorities in environmental management also adduce the fact that good waste management system enhances corporate competitiveness as it showcases corporate bodies as socially responsible through the building of good corporate image and serves as self regulatory system-Atasu, Guide and Van Wassenhore (2008) and Huisman, Magalini, Ruediger, Maurer, Ogilvie, Poll, Delgado, Artim, Szlezak and Stevel (2008). These benefits have reminded elusive in Nigeria environmental management especially considering the activities of Multinational Trading Companies in the food and drink industries. It is therefore recommended that the management of waste system in Nigeria should be based on input of social planners, following good quality forecasting of the actions of manufacturers and consumers using acceptable waste collection rate and recycling rate, that are capable of maximizing total societal welfare. This will build into the system, expected manufacturers profit, consumers surplus and environmental benefits.

Based on good quality environmental education, consumers should be educated on what is required of them given marketing take back programme, and method of rewarding manufacturers for recycling wastes based on take back subsidies. This education has the propensity to increasing the public willingness to-pay for avoiding the harm to the environment. Government through her environmental protection agencies should periodically measure the environmental impact of manufacturing and production as the weight of the hazardous waste; thus should take cognizance of the recycling technology that is in use, the level of environmental friendliness of waste materials; the hazardous nature of the material contents and the physical properties of the products in terms of volume and or weight.

Introduction of subsidy on take-back items should consider the oligopolistic nature of the food and drink industries in Nigeria; as subsidies are optimal only under perfect collection and high environmental hazard. Subsidies, it should be noted increase the enviromental hazard associated with increased output. Thus, balancing these two extremes of subsidy on take-back items on trade off basis is a task for social planners in the Nigeria context-Atasu, Guide and Van Wassenhore [2008].

This Work in addition to the above recommendations, advocates for more strict regulations that will encourage and emphasize waste avoidance and at worst re-use. This will serve as means of keeping used products away from the waste stream as used products are recycled for re-use. This regulation thus should encourage efficiency in collection system among organizations- Husiman, Magalini, Rueliger, Mauror, Ogilvie, Poll, Delgado, Aritim, Szlezak and Stevel (2008).

\section{Conclusion}

Firms in Nigeria given good quality reverse logistic management are assured of low (reduced) cost of operation in the long-term, hence profitability is assured; customers are provided with outstanding customer service; customer feedback such as complaints of dis-services, as deficiencies and process problems are managed; good reputations are earned based on good quality services resulting from good quality reverse logistics management, hence firms gain edge over industrial competitors and continuous improvement is assured based on cost reduction, elimination of inefficiencies and improved customer services. 


\section{References}

Agrewal, V., Atasu, A., \& Van Ittersum, K. (2012). Remanufacturing, Third -party Competitive and Consumers' Perceived Value of New Products. Working Paper, Georgia Institute of Technology. http://dx.doi.org/10.1787/5k9csvvntt8p-en

Andel, T., \& Archlmayr, M. (2002). Turning Returns into cash. Transportation Distribution, 43(8), 29-39.

Atasu, A., \& Van Wassenhore, L. N. (2010). Environmental Legislation on Product Take-Back and Recovery. In Ferguson, M., \& Souza, G. (Eds.), Closed-Loop Supply Chains: New Developments to Improve the Sustainability of Business Practices (pp. 23-28). Boca Raton. FL: CRC Press. http://dx.doi.org/10.1201/9781420095265-c3

Atasu, A., Guide Daniel, V. R. Jr., \& Van Wassenhore, L. N. (2008). Product Reuse Economics in Closed-Loop Supply Chain Research. Production and Operations Management, 17(5), 483-496. http://dx.doi.org/10.3401/poms.1080.0051

Atasu, A., Van Wassenhore, L. N., \& Sarvary, M. (2009). Efficient Tack-back Legislation. Production and Operations Management, 18(3), 243-258. http://dx.doi.org/10.1111/j.1937-5956.2009.01004.x

Bartholomew, D. (1998). It Delivers for UPS. Industry Week, December 21.

Beamon, B. M. (2008). Sustainability and the Future of Supply Chain Management. Operation Supply Chain Management, I, 4-18.

Berkowitz, E. N., Kerin R. A., Hartley \& Rudelius, W. (2000). Marketing (6th ed.). Boston Burr Ridge Irwin McGraw-Hill.

Blackburn, J. D., Guide, V. D. R. Jr., Souza, G. C., \& Van Wassenhore, L. N. (2004). Reverse Supply Chains for Commercial Returns. California Management Review, 46(2), 6-11. http://dx.doi.org/10.2307/41166207

Chou, M. C. (2009). Return Policies and Co-ordination of Supply Chain. In Ponce, J., \& Karahoca (Eds.), Supply Chain the Way to Flat Organization.

Committee for Economic Development. (1971). Social Responsibility of Business Corporations: A Statement of National Policy. CED, New York.

Dakel, I., \& Akcah, E. (2006). Effects of Random Yield in Remanufacturing with Price-Sensitive Supply and Demand. Production and Operations Management, 17(5), 483-496.

Eastlick, M. A., \& Fernberg, R. A. (1994). Call of the Mail (pp. 1-3). EDR Forest.

Eastlick, M. A., \& Feinberg, R. A. (1996). Black; Hip and Primed to Shop (pp. 52-58). American Demographics.

Ezejelue, A. C., Ogwo, E. O., \& Nkamnebe, A. D. (2008). Basic Principles in Managing Research Projects (2nd ed.). Aba-Nigeria: Afritowers Limited.

Ferguson, M., Fleischmann, M., \& Souza, G. (2011). A Profit Maximizing Approach to Disposition Decisions $\begin{array}{lllll}\text { for } & \text { Product } & \text { Returns. } & \text { Decision } & \text { Sciences, }\end{array}$ http://dx.doi.org/10.1111/j.1540-5915.2011.00330.x

Ferguson, M., Guide, Jr. V. D., \& Souza, G. (2006). Supply Chain Co-ordination for False Failure Returns. $\begin{array}{llll}\text { Manufacturing } \& \text { Services } \quad \text { Operations } & \text { Management, }\end{array}$ http://dx.doi.org/10.1287/msom.1060.0112

Fleischmann, M., Brullens, P., Bloenhof-Ruwaard, J. R., \& Van Wassenhore, L. N. (2001). The Impact of Product Recovery on Logistics Network Design. Production and Operations Management, 10(2), 156-173. http://dx.doi.org/10.1111/j.1937-5956.2001.tb00076.x

Fleischmann, M., Galbreth, M. R., \& Tagaras, G. (2010). Product Acquisition, Grading and Disposition Decisions. In M. Ferguson \& G. Souza (Eds.), Closed-loop Supply Chains (pp. 23-38). New Developments to Improve the Sustainability of Business Practices Boca Raton, FL: CRC Press.

French, M. L., \& LaForge, R. L. (2006). Closed-loop Supply Chains in Process Industries: An Empirical Study of Producers Re-use Issues. Journal of Operations Management, 24, 271-286. http://dx.doi.org/10.1016/j.jom.2004.07.012

Galbreth, M., Boyaci, T., P., \& Verter, V. (2012). Product Reuse in Innovation Industries. Production and Operations Management. http://dx.doi.org/10.1111/j.1937-5956.2012.01330.x 
Gongyian, L., \& Hui, H. (n. d.). Design Strategy for the Reserves Supply Chain Based on Time Value of Product. Journal on Innovation and Sustainability, 2(1), 76-80.

Green, K., Morton, B., \& New, S. (1999). Green Purchasing and Supply Policies: Do They Improve Companies Environmental Performance? Supply Chain Management, 12, 332-342.

Guide Daniel, V. R. Jr., \& Van Wassenhore, L. N. (2003). Business Aspects of Closed-Loop Supply Chains. Pithsburgh, PA: Carngir Mellon University Press.

Guide Daniel, V. R. Jr., Souza, G. C., Van Wassenhore, L. N., \& Blackburn, J. O. (2006). Management Science.

Guide Daniel, V. R. Jr., Teunter, R., \& Van Wassenhore, L. N. (2003). Matching Supply and Demand to maximize Profits in Remanufacturing. Manufacturing Service Operations Management, 5, 303-316. http://dx.doi.org/10.1287/msom.5.4.303.24883

Hawkins, D. I., Best, R. J., \& Coney, K. A. (2001). Consumer Behaviour; Building Marketing Strategy. Boston Burr Riage, Irwin McGraw-Hill.

Hervani, A. A., Hetins, M. M., \& Sarkis, J. (2005). Performance Measurement for Green Supply Chain $\begin{array}{lllll}\text { Management. Benchmark International 330-353. } & \text { Journal, }\end{array}$ http://dx.doi.org/10.1108/14635770510609015

Hoffman, W. (2008). Supplying Sustainability. Traffic World, April 7.

Huisman, J., Magalini, F., Ruediger, K., Maurer, C., Ogilvie, S., Poll, J., Delgado, C., Artim, E., Szlezak, J., \& Stevels, A. L. N. (2008). 2008 Review of Directive 2002/96 on WEEE Final Report United National University Report. Study No. 07010401/2006/442493/ETU/G4.

Hume, S., \& Strand, P. (1989). Consumers Go Green. Advertising Age.

International Solid Waste Association (ISWA). (2003). Position on RI and DIO Criteria in the EU Waste Framework Directive. Retrieved from http//www.iswa.org

Jacobs, B., \& Subramanian, R. (2012). Sharing Responsibility for Product Recovery across the Supply Chain. $\begin{array}{llll}\text { Production and } \quad \text { Operations } & \text { 85-100. }\end{array}$ http://dx.doi.org/10.1111/j.1937-5956.2011.01246.x

Jahre, M. (1995). Household Waste Collection as a Reverse Channel: A theoretical Perspective. International Journal of Physical Distribution and Logistics, 25(2). http://dx.doi.org/10.1108/09600039510757666

Kilbourne, W. E. (1995). Green Advertising. Journal of Advertising, Summer, 7-19. http://dx.doi.org/10.1080/00913367.1995.10673472

Kotler, P., \& Armstrong, G. (2006). Principles of Marketing (11th ed.). New Delhi: Prentice -Hall of India Private Limited.

Kotler, P., \& Armstrong, G. (2010). Principles of Marketing (13th ed.). New York. Pearson Education Limited.

Kotler, P., \& Keller, K. L. (2009). Marketing Management (13th ed.). London Pearson Prentice Hall Limited.

Kwak, M. E., \& Kim, H. (2013). Market Positioning of Remanufactured Products with Optimal Planning for part Upgrades. Journal of Mechanical Design, 135, 1-10.

Mobley, A. S. et al. (1995). Consumer Evaluation of Recycled Products. Psychology and Marketing, May, 165-76. http://dx.doi.org/10.1002/mar.4220120302

Newman B. I. (1999). Handbook of Political Marketing. Thousands Oaks, CA: Saga Publications.

Newman, B. I. (1999). The Mass Marketing of Politics. Thousands Oaks, CA: Saga Publications.

Olugu, E. U., Wong Kuan, V., \& Shadaroun, A. M. (2010). A Comprehensive Approach in Assessing the Performance of An Automobile Closed-Loop Supply Chain. Sustainability, 2, 871-887. http://dx.doi.org/10.3390/su2040871

Ostlin, J., Sundin, M. K., \& Bjorkman, M. (2008). Importance of Closed-Loop Supply Chain Relationships for Product Manufacturing. International Journal of Production Economies, 115, 336-348. http://dx.doi.org/10.1016/j.jpe.2008.02.020

Ottman, J. (1998). Innovative Marketers Give New Products the Green Light. Marketing News, March, 10.

Padmonabhun, V., \& Png, T. (1995). Returns Policies: Make Money by Making Goods. Sloan Management Review, 37(1), 65-72. 
Papp, D. S. (1988). Contemporary International; Relations; Framework for Understanding (2nd ed.). New York: Macmillan Publishing Company.

Plambeck, E., \& Wang, Q. (2009). Effects of e-waste Regulation on New Product Introduction. Management Science, 55(3), 333-347. http://dx.doi.org/10.1287/mnsc.1080.0970

Pohlen, T. L., \& Farris, T. M. (1992). Reverse Logistics in Plastics Recycling. International Journal of Physical Distribution and Logistics, 22(7). http://dx.doi.org/10.1108/09600039210022051

Ros, P. (2002). Greening of the Supply Chain: A New Initiative in South East Asia. International Journal of Operation Production Management, 22, 632-655. http://dx.doi.org/10.1108/01443570210427668

Schuttmann, F., Zumkeller, M., \& Rentz, O. (2006). Modeling Reverse Logistic Tasks within Closed-loop Supply Chains: An Example from the Automotive Industry. European Journal of Operations Research, 171, 1033-1050. http://dx.doi.org/10.1016/j.ejor.2005.01.016

Souza, G. C. (2013). Closed-loop Supply Chains: A Critical Review and Future Research. Decision Sciences, 44(1). http://dx.doi.org/10.1111/j.1540-5915.2012.00394.x

Spengler, T., Stolting, W., \& Ploog, M. (2004). Recovery Planning in Closed-loop Supply Chain: An Activity Analysis Based Approach. In Dyckhoff, H., Lackes, R., \& Reese, J. (Eds.), Supply Chain Management and Reverse Loogistics (pp. 61-89). Berlin, Germany: Springer-Verlag. http://dx.doi.org/10.1007/978-3-540-24815-6_4

Srivastara, S. K. (2007). Green Supply Chain Management: A State of the Art Literature Review. International Journal of Management Review, 9, 53-80. http://dx.doi.org/10.1111/j.1468-2370.2007.00202.x

Stafford, M. R., Stafford, T. F., \& Chowdhury, J. (1996). Pre-disposition toward Issues. Journal of Current Issues and Research in Advertising, Spring, 68-79.

Toyasaki, F., Boyac, T., \& Verter. (2011). An Analysis of Monopolistic and Competitive Take-back Schemes for WEEE Recycling. Production and Operation Management, 20(6), 805-823. http://dx.doi.org/10.1111/j.1937-5956.2010.01207.x

Trowbridge, P. A. (2006). A Case Study of Green Supply Chains Management at Advanced Micro Devices. In Sarki J. (Ed.), Greening the Supply Chain (pp. 293-306). London UK: Springer-Verlag. http://dx.doi.org/10.1007/1-84628-299-3_17

Troy, L. C. (1993). Consumer Environmental Consciousness. In Gravens D. W., \& Dickson, P. R. (Eds.), Enhancing Knowledge Development in Marketing. Chicago American Marketing Association.

Tsoulfas, G. T., \& Pappis, C. P. (2008). A Model for Supply Chains Environmental Performance Analysis and Decision Making. Journal of Clean Production, 16, 1647-1659. http://dx.doi.org/10.1016/j.jclepro.2008.04.018

Uzoma, A. (2000). Marketing Organization. New York: Roland Press.

Van Ahzen, A. (2006). Environmental Management in Automotive Supply Chains: An Empirical Analysis. In Sarki, J. (Ed.), Greening the Supply Chain (pp. 203-306). London UK: Springer-Verlag.

Wood, S. (2001). Remote Purchase Environments: The Influence of Returns Policy Tendency on Two-Stage Decision Processes. Journal of Marketing Research, 38, 157-169. http://dx.doi.org/10.1509/jmkr.38.2.157.18847

Zhu, Q., Sarki, J., \& Lai, K. (2007a). Initiative and Outcomes of Green Supply Chain Management Implementation by Chinese Manufacturers. Journal of Environmental Management, 85, 179-189. http://dx.doi.org/10.1016/j.jenvman.2006.09.003

Zhu, Q., Sarki, J., \& Lai, K. (2007b). Green Supply Chain Management: Pressures, Practices and Performance Work the Chinese Automobile Industry Journal. Journal of Clean Production, 15, 1041-1052. http://dx.doi.org/10.1016/j.jclepro.2006.05.021

Zhu, Q., Sarki, J., \& Lai, K. (2008). Green Supply Chain Management Implication for Closing the Loop. Transportation Research Part E, 44, 1-18. http://dx.doi.org/10.1016/j.tre.2006.06.003

Zikopoulos, C., \& Tagaras, G. (2008). On the Attractiveness of Sorting Before Disassembly in Remanufacturing. IIE Transactions, 40(3), 313-323. http://dx.doi.org/10.1080/07408170701488078

Zinkham, G. M., \& Carlson, L. (1995). Green Advertising and the Reluctant Consumers. Journal of Advertising, Summer, 1-6. http://dx.doi.org/10.1080/00913367.1995.10673471 


\section{Copyrights}

Copyright for this article is retained by the author(s), with first publication rights granted to the journal.

This is an open-access article distributed under the terms and conditions of the Creative Commons Attribution license (http://creativecommons.org/licenses/by/3.0/). 